\title{
HUBUNGAN DUKUNGAN KELUARGA DENGAN TINGKAT PENGETAHUAN PERAWATAN PENDERITA SKIZOFRENIA DI KLINIK JIWA RSD MANGUSADA BADUNG
}

\author{
Nur Cahyaningsih ${ }^{1}$, I Made Dwie Pradnya Susila, ${ }^{1, *}$ \\ STIKES Bina Usada Bali ${ }^{l}$ \\ e-mail: dwiepradnya@gmail.com*
}

\begin{abstract}
Schizophrenic patients have decreased ability to maintain daily care. Family support in the care of schizophrenic patients is influenced by the knowledge of schizophrenic patient care by the family which can give a positive response in daily care for schizophrenic patients. This study aimed at determining the correlation between family support and the level of knowledge in the care of schizophrenics at the Mental Clinic of RSD Mangusada Badung. The study was implemented with an analytic observational design with a cross-sectional approach. The total samples were 67 respondents using the incidental sampling technique. Data were collected using a family support questionnaire and a questionnaire on the level of care knowledge. Data were analyzed using Spearman's rho test. The results of the study were 36 people with adequate family support with a percentage of 53.7\% and 36 people with a high level of knowledge of care with a percentage of 53.7\%. correlation analysis between family support and the level of knowledge of care obtained p-value $<0.001$. There was a correlation between family support and the level of knowledge of schizophrenic care in Mental Clinic RSD Mangusada Badung. The recommendations of this study are expected to be input for nurses to always provide care education for schizophrenia patients to their families.
\end{abstract}

Keywords: family support, knowledge, Schizophrenia

\begin{abstract}
ABSTRAK
Pasien skizofrenia mengalami penurunan kemampuan untuk mempertahankan perawatan sehari-hari. Dukungan keluarga dalam perawatan pasien skizofrenia dipengaruhi oleh pengetahuan tentang perawatan pasien skizofrenia oleh keluarga yang dapat memberikan respon positif dalam perawatan sehari-hari pasien skizofrenia. Penelitian ini bertujuan untuk mengetahui hubungan dukungan keluarga dengan tingkat pengetahuan dalam asuhan keperawatan skizofrenia di Klinik Jiwa RSD Mangusada Badung. Penelitian dilaksanakan dengan desain observasional analitik dengan pendekatan cross sectional. Jumlah sampel sebanyak 67 responden dengan teknik insidental sampling. Pengumpulan data menggunakan kuesioner dukungan keluarga dan kuesioner tingkat pengetahuan perawatan. Data dianalisis menggunakan uji Spearman`s rho. Hasil penelitian adalah 36 orang dengan dukungan keluarga cukup dengan persentase 53,7\% dan 36 orang dengan tingkat pengetahuan perawatan tinggi dengan persentase $53,7 \%$. analisis korelasi antara dukungan keluarga dengan tingkat pengetahuan perawatan diperoleh p-value $<0,001$. Ada hubungan antara dukungan keluarga dengan tingkat pengetahuan perawatan skizofrenia di Klinik Jiwa RSD Mangusada Badung. Rekomendasi penelitian ini diharapkan dapat menjadi masukan bagi perawat untuk selalu memberikan edukasi perawatan pasien skizofrenia kepada keluarganya.
\end{abstract}

Kata kunci: dukungan keluarga, pengetahuan, Skizofrenia

\section{PENDAHULUAN}

Penduduk yang mengalami berbagai permasalahan dan tekanan hidup dapat menjadi stress berat dan lama-kelamaan menjadi sakit jiwanya. Sebagai akibatnya, muncul gejala skizofrenia dimana jiwa dari individu menjadi terpecah dan terjadi disharmoni antara pikiran dan kemauan (Yosep, 2010). Skizofrenia adalah suatu penyakit yang mempengaruhi otak dan menyebabkan timbulnya pikiran, persepsi, emosi, gerakan dan perilaku aneh dan terganggu. Skizofrenia tidak dapat didefinisikan sebagai penyakit tersendiri, melainkan diduga sebagai suatu sindrom atau proses penyakit yang mencakup banyak jenis dengan berbagai gejala. Skizofrenia sebagai penyakit neurologis yang memengaruhi persepsi pasien, cara berpikir, bahasa, emosi, dan perilaku sosialnya (Hastuti \& Rohmat, 2018). Di zaman sekarang penderita dengan gangguan jiwa semakin banyak mengalami peningkatan jumlah (Farkhah \& Suryani, 2017). 
Masalah gangguan kesehatan jiwa di seluruh dunia memang sudah menjadi masalah yang cukup serius.Skizofrenia menduduki peringkat 4 dari 10 besar penyakit yang membebankan di seluruh dunia. Badan kesehatan dunia (WHO) pada Tahun 2016 mengemukakan terdapat 21 juta orang terkena skizofrenia. Prevalensi di Indonesia menurut Riskesdas (2013), penderita skizofrenia mencapai 1,7 per 1000 penduduk atau sekitar 400.000 orang sedangkan mengalami peningkatan tahun 2018 penderita skizofrenia sebanyak $6,7 \%$ per 1000 rumah tangga. Berdasarkan Riskesdas (2013)Provinsi Bali menduduki posisi nomor empat dengan prevalensi skizofrenia sebesar 0,23 dan menurut Riskesdas, (2018) Provinsi Bali menduduki pringkat satu jumlah penderita skizofrenia sebanyak $11 \%$ per mil. Menurut data 10 besar penyakit rawat inap di RSJ Provinsi Bali tahun 2018, penyakit skizofrenia merupakan penyakit dengan penderita terbanyak yaitu 3.553 penderita. Prevalensi kunjungan penderita skizofrenia RSD Mangusada Badung tahun 2018 sebanyak 1.670 orang dengan rata-rata perbulan sebanyak 139 orang dan tahun 2019 jumlah kunjungan penderita skizofrenia sebanyak 2.257 orang dengan rata-rata perbulan sebanyak 188 orang dan bulan Januari 2020 jumlah penderita skizofrenia sebanyak 235 orang.

Pasien skizofrenia mengalami penurunan pada aktivitas sehari-hari karena kehilangan motivasi dan apatis berarti kehilangan energi dan minat dalam hidup. Hal ini membuat pasien menjadi orang yang malas, mereka tidak bisa melakukan hal-hal yang lain selain tidur dan makan (Yosep, 2010). Keadaan apatis pada skizofrenia menyebabkan terganggunya aktifitas rutin sehari-hari seperti mandi, menyisir rambut, gosok gigi dan tidak mempedulikan kerapian diri atau berpakaian atau berdandan secara eksentrik. Kemandirian dalam aktivitas kehidupan sehari hari seperti mandi, makan, berpakaian, dan toileting yang terganggu menyebabkan penurunan kemandirian perawatan diri pada pasien skizofrenia(Hastuti \& Rohmat, 2018). Penurunan kemampuan perawatan diri dapat dipicu oleh adanya peningkatan kecemasan yang timbul akibat pikiran waham, halusinasi, perilaku kekerasan. Selain itu, hambatan hubungan sosial dapat memperburuk kemampuan perawatan diri (Hastuti \& Rohmat, 2018).

Hubungan sosial penderita skrizofrenia yang paling dekat yaitu keluarga. Salah satu peran keluarga dalam melakukan perawatan pada anggota keluarga yang mengalami gangguan jiwa adalah memberikan perhatian yang lebih kepada anggota keluarga yang mengalami ganggu jiwa seperti memperhatikan kebutuhan sehari-hari klien baik makan, minum, istirahat dan eliminasi(Hastuti \& Rohmat, 2018). Pentingnya dukungan keluarga dalam merawat penderita skizofrenia tentunya akan dipengaruhi oleh pengetahuan keluarga itu sendiri. Pengetahuan keluarga yang baik dapat memberikan pengaruh positif kepada penderita dalam meningkatkan motivasi dan tanggung jawabnya untuk melaksanakan perawatan secara mandiri. Keluarga akan mempunyai sikap yang positif, sehingga akan memberikan respon positif kepada penderita, menghargai penderita sebagai anggota keluarga dan menumbuhkan sikap tanggung jawab pada penderita, sehingga terciptalah suatu lingkungan yang positif(Hastuti \& Rohmat, 2018).

Dukungan keluarga adalah sikap, tindakan penerimaan keluarga terhadap anggota keluarganya, baik berupa dukungan informasional, dukungan penilaian, dukungan instrumental dan dukungan emosional (Friedman, 2010). Dukungan dalam keluarga dibutuhkan oleh setiap anggotanya untuk dapat beradaptasi, bertahan, memecahkan masalah, meningkatkan motivasi, menurunkan stress serta memberikan keyakinan akan kemampuan diri dalam menghadapi masalah (Nurullah, 2012). Dukungan keluarga dapat berupa dukungan keluarga internal, seperti dukungan dari suami/istri atau saudara kandung atau dukungan keluarga eksternal seperti mertua dan keluarga jauh lainnya (Friedman, 2010). Dukungan keluarga pada penderita skizofrenia akan lebih efektif bila berasal dari orang terdekat yang mempunyai arti dalam kehidupan individu yaitu istri atau suami, yang mampu membantu menumbuhkan sikap mandiri dalam diri penderita (Ardiyani, Kumboyono, \& Susmarini, 2017).

Dukungan keluarga merupakan hal yang sangat penting untuk membantu pasien bersosialisasi kembali, menciptakan kondisi lingkungan suportif, menghargai pasien secara pribadi dan membantu pemecahan masalah pasien (Keliat, Herawata, Panjaitan, \& Helena, 2011). Penelitian sebelumnya dilakukan oleh Saswati, Dasuki, \& Ermayani (2017), menunjukan ada hubungan antara pengetahuan dan perilaku dengan peran keluarga dalam melakukan perawatan pasien skizofrenia di Poli Jiwa Rumah Sakit Jiwa Daerah Provinsi Jambi Tahun 2016. Penelitian sebelumnya dilakukan oleh Saragih \& Indriati (2013), menunjukan sikap responden tentang perawatan anggota keluarga dengan perilaku kekerasan dirumah adalah negatif sebanyak 21 responden $(63,6 \%)$ dan sikap positif sebanyak 12 orang $(36,4 \%)$. Sikap responden yang negatif dalam penelitian memperlihatkan perlakuan keluarga dengan klien sehari-hari, dimana kebanyakan diantara keluarga pasien jarang melakukan interaksi dengan pasien selama di rumah.

Dukungan informasi merupakan suatu dukungan yang diberikan oleh keluarga dalamupaya meningkatkan status kesehatan melalui peningkatan informasi(Friedman, 2010).Pengetahuan atau kognitif merupakan domain yang sangat penting dalam membentuk tindakan seseorang. Perilaku didasari oleh pengetahuan akan lebih langgeng dari pada perilaku yang tidak didasari oleh pengetahuan. Pengetahuan merupakan faktor predisposing dalam proses pembentukan perilaku individu (Notoatmodjo, 2010). Tingkat pengetahuan sangat berperan dalam perawatan diri pada penderita skizofrenia, semakin tinggi pendidikan seseorang makin mudah menerima informasi sehingga makin banyak pula pengetahuan yang dimiliki (Wahyudin, Ramdani, \& Rahmi, 2014). 


\section{Vol. 16 No.2 Mei - Agustus 2021}

Studi pendahuluan yang dilakukan pada tangal 10 Maret 2020 di Klinik RSD Mangusada Badung didapatkan jumlah penderita bulan Februari sebanyak 196 orang. Dengan metode wawancara dan mengunakan kuesioner terdadap 10 orang penderita skizofrenia didapatkan data tujuh orang dukungan kuluarga sedang dengan pengetahuan perawatan yang kurang sedangkan tiga orang mendapatkan dukungan keluarga baik dengan pengetahuan perawatan yang cukup. Klinik Jiwa RSD Mangusada Badung telah melakukan upaya yang terkait penderita skizofrenia dalam meningkatkan kemandirian perawatan yaitu dengan memberikan terapi dan konseling pada penderita skizofrenia dengan keluarga dalam melatih kemandirian pasien dalam perawatan dirumah.

Berdasarkan urain diatas peneliti tertarik melakukan penelitian hubungan dukungan keluarga dengan tingkat pengetahuan perawatan penderita skizofrenia di Klinik Jiwa RSD Mangusada Badung.

\section{METODE}

Jenis penelitian yang digunakan peneliti yaitu desain kuantitatif dengan rancangan Observasional analitik dengan pendekatan cross sectional. Sampel dalam penelitian ini adalah 67 responden. Teknik pengambilan sampel berdasarkan Isidental sampling. Alat pengumpulan data dengan kuesioner dukungan keluarga dan kuesioner tingkat pengetahuan perawatan. Pada penelitian ini pengolahan data menggunakan program SPSS, data dukungan keluarga dan tingkat pengetahuan perawatan diuji dengan uji Spearman's rho.

\section{HASIL}

1. Karakteristik Responden

a. Karakteristik responden berdasarkan usia

\section{Tabel 1}

Distribusi Frekuensi Karakteristik Responden Berdasarkan Usia pada penderita skizofrenia di Klinik Jiwa RSD Mangusada Badung

\begin{tabular}{llll}
\hline Variabel & mean & $\min$ & $\max$ \\
\hline Usia & 44,9 & 21 & 69 \\
\hline Sumber: Data Primer, & 2020 & &
\end{tabular}

Tabel 1 menunjukan rata-rata usia responden yaitu 44,9 tahun, dengan usia mimimal 21 tahun dan usia maksimal 69 tahun.

b. Karakteristik responden berdasarkan jenis kelamin Tabel 2

Distribusi Frekuensi Karakteristik Responden Berdasarkan Jenis Kelamini pada penderita skizofrenia di Klinik Jiwa RSD Mangusada Badung

\begin{tabular}{cll}
\hline Jenis Kelamin & $\mathrm{f}$ & $\%$ \\
\hline Laki-laki & 44 & 65.7 \\
Perempuan & 23 & 34.3 \\
\hline Total & 67 & 100 \\
\hline
\end{tabular}

Sumber: Data Primer, 2020

Tabel 2 menunjukan sebagian besar responden berjenis kelamin laki-laki yaitu 44 orang $(65,7 \%)$.

c. Karakteristik responden berdasarkan pendidikan

Tabel 3

Distribusi Frekuensi Karakteristik Responden

Berdasarkan Pendidikan padapenderita skizofrenia di Klinik Jiwa RSD

Mangusada Badung

\begin{tabular}{lll}
\hline Pendidikan & $\mathrm{f}$ & $\%$ \\
\hline Tidak sekolah & 17 & 25.4 \\
SD & 19 & 28.4 \\
SMP & 14 & 20.9 \\
SMA & 17 & 25.4 \\
\hline Total & 67 & 100 \\
\hline
\end{tabular}

Sumber: Data Primer, 2020

Tabel 3 menunjukan sebagian besar responden pendidikan SD sebanyak 19 orang $(28,4 \%)$

d. Karakteristik responden berdasarkan pekerjaan

Tabel 4

Distribusi Frekuensi Karakteristik Responden Berdasarkan Pekerjaan pada penderita skizofrenia di Klinik Jiwa RSD Mangusada Badung

\begin{tabular}{cll}
\hline Pekerjaan & $\mathrm{f}$ & $\%$ \\
\hline Tidak bekerja & 44 & 65.7 \\
IRT & 7 & 10.4 \\
Petani & 11 & 16.4 \\
Wiraswasta & 5 & 7.5 \\
\hline Total & 67 & 100 \\
\hline
\end{tabular}

Sumber: Data Primer, 2020

Tabel 4 menunjukan sebagian besar responden tidak bekerja yaitu sebanyak 44 orang $(65,7 \%)$.

e. Karakteristik responden berdasarkan Diagnosa Keperawatan

Tabel 5

Distribusi Frekuensi Karakteristik Responden Berdasarkan diagnosa keperawatan pada penderita skizofrenia di Klinik Jiwa RSD Mangusada Badung

\begin{tabular}{lll}
\hline Diagnosa Keperawatan & f & $\%$ \\
\hline $\begin{array}{l}\text { Halusinasi interaksi } \\
\text { kerusakan int }\end{array}$ & 43 & 64.2 \\
$\begin{array}{l}\text { sosial } \\
\text { resiko perilaku } \\
\text { kekerasan }\end{array}$ & 5 & 12.9
\end{tabular}




\begin{tabular}{lll} 
harga diri rendah & 1 & 1.5 \\
waham & 6 & 9 \\
\hline Total & 67 & 100 \\
\hline Sumber: Data Primer, & 2020 &
\end{tabular}

Tabel 5 menunjukan sebagian besar responden dengan diagnosa keperawatan halusinasi yaitu sebanyak 43 orang $(64,2 \%)$.

\section{Dukungan Keluarga pada Penderita Skizofrenia} di Klinik Jiwa RSD Mangusada Badung

Tabel 6

Distribusi Frekuensi Dukungan Keluarga Pada penderita skizofrenia di Klinik Jiwa RSD Mangusada Badung

\begin{tabular}{lll}
\hline Dukungan Keluarga & $\mathrm{f}$ & $\%$ \\
\hline Baik & 17 & 25.4 \\
Cukup & 36 & 53.7 \\
Buruk & 14 & 20.9 \\
\hline Total & 67 & 100 \\
\hline
\end{tabular}

Sumber: Data Primer, 2020

Tabel 6 menunjukan hasil pengukuran dukungan keluarga sebagian besar dukungan keluarga cukup sebanyak 36 orang dengan persentase $53,7 \%$.

3. Tingkat Pengetahuan Perawatan Penderita Skizofrenia di Klinik Jiwa RSD Mangusada Badung

Tabel 7

Distribusi Frekuensi Tingkat Pengetahuan Perawatan Pada penderita skizofrenia di Klinik Jiwa RSD Mangusada Badung

\begin{tabular}{lll} 
Tingkat & $\mathrm{f}$ & $\%$ \\
$\begin{array}{l}\text { Pengetahuan } \\
\text { Perawatan }\end{array}$ & & \\
\hline Baik & 4 & 6.0 \\
Cukup & 36 & 53.7 \\
Kurang & 27 & 40.3 \\
\hline Total & 67 & 100.0
\end{tabular}

Sumber: Data Primer, 2020

Berdasarkan tabel 7 diketahui tingkat pengetahuan perawatan penderita skizofreniadari 67 responden sebagian besar responden tingkat pengetahuan perawatan cukup sebanyak 36 orang dengan persentase $53,7 \%$.

4. Hubungan Dukungan Keluarga Dengan Tingkat Pengetahuan Perawatan Penderita Skizofrenia di Klinik Jiwa RSD Mangusada Badung

\section{Tabel 8}

Analisis Dukungan Keluarga dengan Tingkat Pengetahuan Perawatan Penderita Skizofrenia di Klinik Jiwa RSD Mangusada Badung

\begin{tabular}{l|l}
\hline & $\begin{array}{l}\text { Tingkat Pengetahuan } \\
\text { Perawatan }\end{array}$ \\
\hline Dukungan keluarga & $\mathrm{r}=0.526$ \\
\cline { 2 - 2 } & $\mathrm{P}<0.001$ \\
\cline { 2 - 2 } & $\mathrm{n}=67$ \\
\hline
\end{tabular}

Sumber: Data Primer, 2020

Tabel 8 berdasarkan uji sperman Rho didapatkan hasil nilai signifikan adalah $\mathrm{p}=0,001$. Jadi nilai signifikansi hitung $(\mathrm{p}=0,001)$ lebih kecil dari nilai signifikansi tabel $(\mathrm{p}<0,05)$. Berarti ada hubungan dukungan keluarga dengan tingkat pengetahuan perawatan penderita skizofrenia di Klinik Jiwa RSD Mangusada Badung.Berdasarkan uji Sperman rho $p>0.05$, terhadap data dukungan keluarga dengan tingkat pengetahuan perawatan penderita skizofrenia didapatkan hasil Correlation Coefficient dengan nilai 0.526 yang artinya korelasi kuat. Dapat disimpulkan ada hubungan yang kuat antara dukungan keluarga dengan tingkat pengetahuan perawatan penderita skizofrenia. Arah hubungan didapatkan positif yang artinya semakin baik dukungan keluarga akan meningkatkan tingkat pengetahuan perawatan penderita skizofrenia.

\section{PEMBAHASAN}

\section{Dukungan Keluarga pada Penderita Skizofrenia di Klinik Jiwa RSD Mangusada Badung}

Hasil penelitian menunjukan adanya tingkatan dukungan keluarga yang bervariasi, tetapi sebagian besar dukungan keluarga cukup sebanyak 36 orang dengan persentase $53,7 \%$ hal ini berarti bahwa, dukungan keluarga pada penderita skizofreniatidak terlalu begitu baik tapi tidak begitu buruk. Penelitian ini sejalan dengan penelitian Fauziah \& Latipun, (2016)didapatkan hasil dukungan keluarga pada penderita skizofrenia dikategorikan cukup yaitu sebanyak 49 orang pasien. sejalan dengan penelitian yang dilakukan oleh Damayantie, Rusmimpong, \& Elly, (2019), menunjukan sebagian besar keluarga memberi dukungan positif yaitu sebanyak 50 orang $(52,1 \%)$. Klien skizofrenia sangat memerlukan dukungan dari keluarga dalam proses penyembuhan klien karena mempunyai peranan yang besar bagi klien skizofrenia. Keberadaan dukungan keluarga yang adekuat terbukti berhubungan dengan menurunnya mortalitas, lebih mudah sembuh dari sakit, fungsi kognitif, fisik dan kesehatan emosi dan mental (Friedman, 2010).

Presentasi jumlah dukungan keluarga sebagian besar cukup dapat dikatakan bahwa dukungan keluarga penderita skizofrenia tidak terlalu baik dan tidak terlalu buruk. Terlihat dari dukungan yang paling dominan diberikan yaitu dukungan emosional dan dukungan instrumental kepada penderita skizofrenia.Dukungan keluarga dapat berupa dukungan sosial internal, seperti dukungan dari suami, istri atau dukungan dari saudara kandung dan dapat juga berupa dukungan keluarga eksternal bagi keluarga inti. Sebagai akibatnya, hal ini 


\section{Vol. 16 No.2 Mei - Agustus 2021}

meningkatkan kesehatan dan adaptasi keluarga (Friedman, 2010).

Klien skizofrenia yang mendapatkan dukungan keluarga mempunyai kesempatan berkembang ke arah yang lebih baik secara maksimal, sehingga klien skizofrenia akan bersikap positif, baik terhadap dirinya maupun lingkungannya karena keluarga merupakan lingkungan sosial pertama yang dikenal. Melalui keluarga yang memiliki ikatan darah dan tentu ikatan batin yang kuat akan sangat membantu klien untuk mendapatkan dukungan dan kebutuhan yang adekuat(Padila, 2012). terapi dukungan keluarga ini sangat efisien untuk menangani kondisi kejiwaan yang tidak menentu, stres traumatik dan efektif untuk mengatasi kecemasan serta gangguan psikologis lainnya. Model terapi dukungan ini mempunyai beberapa tujuan, yaitu: 1) Menambah kekuatan, keahlian, dan kemampuan klien dalam menggunakan sumber daya dalam dirinya. 2) Menurunkan tekanan/distres klien respon maladaptif lainnya. 3) Membantu untuk meningkatkan kemandirian klien (Syamsudin, Susilaningsih, \& P.S, 2015).

Dukungan keluarga juga dipengaruhi beberapa faktor lain salah satunya faktor latar belakang budaya, keyakinan dan nilai sedangkan gangguan jiwa diyakini merupakan penyakit yang disebebkan karena gangguan mental. Dukungan keluarga juga dipengaruhi oleh faktor praktik di keluarga dimana cara keluarga memberikan dukungan biasanya memengaruhi penderita dalam menjaga kesehatannya dan semakin tinggi tingkat ekonomi seseorang biasanya dia akan lebih cepat tanggap terhadap gejala penyakit yang dirasakan sehingga ia akan segera mencari pertolongan ketika ada gangguan pada kesehatannya(Suyanto, 2015)

Dukungan keluarga sangat dibutuhkan oleh penderita skizofrenia dalam menjalani pengobatan, melakukan kehidupan sehari-hari dan dalam kegiatan sosial. Dukungan keluarga yang diberikan kepada penderita skizofrenia yaitu dukungan berupa mengantar dan menemani penderita dalam melakukan pengobatan sampai tuntas dan memberikan dukungan sosial dalam pergaulan serta perilaku yang benar dalam kehidupan sehari-hari. Hasil pengamatan peneliti dukungan keluarga yang diberikan dengan cara mengantar penderita skizofreniamelakukan pemeriksaan kesehatan ke fasilitas kesehatan secara rutim dan keluarga juga bertanya kepada petugas kesehatan tentang kepatuhan mengkonsumsi obat dan resiko bila obat tidak patuh dikomsumsi. Keluarga juga bertanya secara aktif tentang kemungkinan pasien akan mengalami kekambuhan.

\section{Tingkat Pengetahuan Perawatan Penderita Skizofrenia di Klinik Jiwa RSD Mangusada Badung}

Tingkat pengetahuan perawatan penderita skizofrenia dari 67 responden sebagian besar tingkat pengetahuan perawatan penderita skizofrenia cukup yaitu sebanyak 36 orang dengan persentase 53,7\%. Hal ini menunjukan bahwa tingkat pengetahuan perawatan penderita skizofrenia di Klinik RSD Mangusada Badung dapat dikatakan tidak baik dan tidak buruk. Penelitian ini sejalan dengan penelitian Saragih, Jumaini, \& Indriati, (2013)didapatkan tingkat pengetahuan dan sikap keluarga tentang perawatan pasien resiko perilaku kekerasan di rumah sebagian besar pengetahuan kurang yaitu sebanyak 15 orang $(40,5 \%)$. Pengetahuan pada keluarga klien skizofrenia adalah hasil dari tahu dan memahami setelah orang melakukan penginderaan terhadap suatu objek tertentu. Keluarga diharapkan dapat lebih mengerti, mengetahui dan memahami yang pada akhirnya dapat berperan secara aktif sebagai pendukung utama bagi penderita yang juga akan meningkatkan kemampuan penyesuaian dirinya serta tidak rentan lagi terhadap pengaruh stresor psikososial.

Menurut Budiman \& Riyanto (2014), pengatahuan adalah hasil dari tahu dan ini terjadi setelah orang melakukan pengindraan terhadap suatu objek tertentu. Pengindraan terjadi melalui panca indra manusia yaitu indra penglihatan, indra pendengaran, indra penciuman, indra perasa dan indra peraba, sebagian besar pengetahuan manusia diperoleh melalui mata dan telinga. Pengetahuan adalah suatu hasil dari rasa keingintahuan melalui proses sensoris, terutama pada mata dan telinga terhadap objek tertentu. Pengetahuan merupakan domain yang penting dalam terbentuknya perilaku terbuka atau open behavior (Donsu, 2017)

Tingkat pengetahuan perawatan penderita skizofrenia yang cukup juga dipengaruhi oleh beberapa faktor yaitu sosial ekonomi dimana lingkungan sosial akan mendukung tingginya pengetahuan seseorang. Bila ekonomi baik, maka tingkat pendidikan akan tinggi. Jika pendidikan tinggi maka tingkat pengetahuan akan tinggi juga serta faktor budaya dimana budaya sangat berpengaruh terhadap tingkat pengetahuan seseorang karena informasi yang baru akan disaring atau tidak dengan budaya yang ada atau agama yang dianut (Budiman \& Riyanto, 2014).

Tingkat pengetahuan perawatan pada pasien skizofrenia sangat tergantung pada pengetahuan yang di dapat dari berbagai sumber termasuk penjelasan yang diberikan oleh tenaga kesehatan. Pengetahuan tersebut yang akan membimbing pasien skizofrenia dalam merawat diri secara mandiri. Hasil dari pengamatan peneliti terbanyak pasien skizoprenia cukup kelihat rapi dalam melakukan pengobatan ke rumah sakit dan keluarga mengatakan selalu memperhatikan kebersihan sehari-hari. 


\section{Analisis Hubungan Dukungan Keluarga dengan Tingkat Pengetahuan Perawatan Penderita Skizofrenia di Klinik Jiwa RSD Mangusada Badung}

Hasil menunjukan ada hubungan yang kuat antara dukungan keluarga dengan tingkat pengetahuan perawatan penderita skizofrenia dengan hasil $p$ value 0,001 lebih kecil dari $p$ value tabel 0,05 dan menunjukan semakin tinggi dukungan keluarga semakin meningkatkan tingkat pengetahuan perawatan penderita skizofrenia. Penelitian ini sejalan dengan peneliti Saswati, Dasuki, \& Ermayani (2017)didapatkan hasil ada hubungan perilaku keluarga dengan peran keluarga dalam melakukan perawatan pasien skizofrenia dengan nilai $p$-value $=$ $0.017(\mathrm{p}<0.05)$. Masalah perawatan skizofrenia pada pasien skizofrenia tidak terlepas dari pengetahuan keluarga. Selama pasien skizofrenia dalam proses penyembuhan dan perawatan skizofrenia, sebaiknya keluarga lebih menggali lagi pengetahuan dan cara merawat pasien skizofrenia dengan baik agar pasien cepat sembuh dari penyakitnya. Keluarga dapat melakukan tindakan perawatan mandiri, pencegahan dan pengobatan skizofrenia dirumah.

Menurut Irianto (2014), skizofrenia juga diartikan sebagai sekelompok gangguan berat pada otak di mana orang akan menafsirkan realitas dengan abnormal, tidak seperti orang pada umumnya. Skizofrenia merupakan penyakit neurologis yang mempengaruhi persepsi klien, cara berpikir, bahasa, emosi, dan perilaku sosialnya (Direja, 2011). Skizofrenia dibagi menjadi dua fase yaitu: fase akut: fase mulai munculnya gejala sampai dengan sebelum 6 bulan, ditandai dengan gejala positif dan negatif. fase kronik: diagnosis Skizofrenia kronik ditandai dengan gejala akut, sudah berlangsung 6 bulan atau lebih, disertai tidak memerhatikan kebersihan diri dan gangguan motorik atau pergerakan (Keliat, Herawata, Panjaitan, \& Helena, 2011).

Jalil (2015), menyatakan bahwa pasien dengan Skizofrenia sulit melaksanakan perawatan diri secara mandiri karena adanya gangguan fungsi kognitif yang ditandai dengan buruknya orientasi realitas mengakibatkan menurunnya tingkat kesadaran pasien dalam melakukan perawatan diri seperti makan, mandi, berpakaian, istirahat dan upaya lain untuk keselamatan diri. Damaiyanti \& Iskandar (2014), menyebutkan bahwa intervensi yang dapat keluarga lakukan dalam perawatan pasien skizofrenia yaitu: keluarga menyiapkan sarana dalam kebersihan diri, keluarga membantu dan membimbing pasien dalam menjaga kebersihan diri seperti mengingatkan waktu mandi, sikat gigi, keramas, ganti baju, makan, serta eliminasi, membantu pasien apabila mengalami hambatan dan memberi pujian atas keberhasilan pasien dan membuat jadwal aktivitas di rumah termasuk minum obat (discharge planning).
Dukungan keluarga adalah sebuah proses yang terjadi sepanjang masa kehidupan, sifat dan jenis dukungan berbeda dalam berbagai tahap-tahap siklus kehidupan. Dukungan keluarga dapat berupa dukungan sosial internal, seperti dukungan dari suami, isteri, atau dukungan dari saudara kandung, dan dapat juga berupa dukungan keluarga eksternal bagi keluarga inti. Dukungan keluarga membuat keluarga mampu berfungsi dengan berbagai kepandaian dan akal. Sebagai akibatnya, hal ini meningkatkan kesehatan dan adaptasi keluarga (Friedman, 2010).

Dukungan keluarga yang diberikan yaitu dukungan emosional, dukungan informasi, dukungan instrumental dan dukungan penghargaan akan diterima oleh talamus (salah satu bagian otak yang berfungsi menerima pesan dari indara dan diteruskan kebagian otak lain). Amigdala juga menerima sinyal dari semua bagian korteks limbik (emosi /prilaku) seperti juga neokortekslobus temporal (korteks atau lapisan otak yang hanya ada pada manusia) parietal (bagaian otak tengah) dan oksipital (otak belakang).Talamus juga menjalankan sinyal ke neokorteks (area otak yang berfungsi untuk berfikir atau mengolah data serta infomasi yang masuk ke otak).Di neokorteks sinyal disusun menjadi benda yang di pahami dan dipilah menurut maknanya, sehingga otak mengenali masing masing objek dan arti kehadirannya. Kemudian amigdala menjalankan sinyal ke hipokampus(Primadita, 2011).

Hipokampus sangat penting untuk membantu otak dalam menyimpan ingatan yang baru. Hal ini dimungkinkan karena hipokampus merupakan salah satu dari sekian banyak jalur keluar penting yang berasal dari area "ganjaran" dan "hukuman". Diantara motivasi-motivasi itu terdapat dorongan dalam otak untuk mengingat pengalaman-pengalaman, pikiranpikiran yang menyenangkan, dan tidak menyenagkan.Dukungan keluarga akan memberikan kesan positif pada hipokampus dan amigdala sehingga menimbulkan ingatan kembali tentang perawatan diri dan menambah ingatan baru tentang perawatan diri sehingga dapat merubah prilaku(Primadita, 2011).

Pentingnya dukungan keluarga dalam merawat penderita skizofrenia tentunya akan dipengaruhi oleh pengetahuan keluarga itu sendiri. Pengetahuan keluarga yang baik dapat memberikan pengaruh positif kepada penderitadalam meningkatkan motivasi dan tanggung jawabnya untuk melaksanakan perawatan secara mandiri. Keluarga akan mempunyai sikap yang positif, sehingga akan memberikan respon positif kepada penderita, menghargai penderita sebagai anggota keluarga dan menumbuhkan sikap tanggung jawab pada penderita, sehingga terciptalah suatu lingkungan yang positif(Hastuti \& Rohmat, 2018).

\section{KESIMPULAN}

Berdasarkan uji sperman Rhodidapatkan hasil nilai signifikan adalah $\mathrm{p}=0,001$ jadi terdapathubungan antara dukungan keluarga dengan tingkat pengetahuan 


\section{Vol. 16 No.2 Mei - Agustus 2021}

perawatan penderita skizofrenia di Klinik Jiwa RSD Mangusada Badung, yaitu semakin tinggi dukungan keluarga akan meningkatkan tingkat pengetahuan perawatan penderita skizofrenia.

\section{DAFTAR PUSTAKA}

1. Ardiyani, V. M., Kumboyono, \& Susmarini, D. (2017). Pengaruh Dukungan Keluarga Terhadap Peningkatan Adaptasi Pasien Skizophrenia. Jurnal Care, 5(1), 123-129.

2. Baradero, M. (2014). Seri Asuhan Keperawatan Kesehatan Mental Psikiatri. Jakarta: EGC.

3. Budiman, \& Riyanto, A. (2014). Kapita Selekta Kuesioner Pengetahuan Dan Sikap Dalam Penelitian Kesehatan. Jakarta:Salemba Medika

4. Damaiyanti, \& Iskandar. (2014). Asuhan Keperawatan Jiwa. Bandung: Refika Aditama.

5. Damayantie, N., Rusmimpong, R., \& Elly. (2019). Hubungan Pengetahuan Dan Dukungan Keluarga Dengan Kepatuhan Kontrol Berobat Pasien Skizofrenia Di Poli Jiwa Rsjd Provinsi Jambi Tahun 2018. Jurnal Bahana Kesehatan Masyarakat (Bahana of Journal Public Health), 3(1), 1-5

6. Dhuangga, \& Paramitha, W. (2012). Efektifitas Pendidikan Kesehatan Tentang Hygiene Kewanitaan Terhadap Pengetahuan Dan Sikap Remaja Putri Dalam Menangani Keputihan. Jurnal Ners Indonesia, 2(2).

7. Direja, A. H. S. (2011). Buku Ajar Asuhan Keperawatan Jiwa. Yogyakarta: Nuha Medika.

8. Donsu, J. D. (2017). Psikologi Keperawatan. Yogyakarta: Pustaka Baru Press.

9. Farkhah, L., \& Suryani, S. (2017). Faktor Caregiver dan Kekambuhan Klien Skizofrenia. Jurnal Keperawatan Padjadjaran, 5(1), 37-46.

10. Fauziah, S., \& Latipun. (2016). Hubungan Dukungan Keluarga dan Keberfungsian Sosial pada Pasien Skizofrenia Rawat Jalan. Jurnal Ilmiah Psikologi Terapan, 04(02), 140-160.

11. Friedman. (2010). Buku Ajar Keperawatan Keluarga : Riset, Teori, Dan Praktek. Jakarta:EGC.

12. Hastuti, R. Y., \& Rohmat, B. (2018). Pengaruh Pelaksanaan Jadwal Harian Perawatan Diri Terhadap Tingkat Kemandirian Merawat Diri Pada Pasien Skizofrenia Di Rsjd Dr. Rm Soedjarwadi Provinsi Jawa Tengah. Gaster, 16(2), 177.

13. Hidayat, A. A. A. (2014). Metode Penelitian Kebidanan dan Teknik Analisis Data.Jakarta: Salemba Medika.
14. Irianto, koes. (2014). Memahami Berbagai Macam Penyakit. Bandung: Alfabeta

15. Jalil, A. (2015). faktor Yang Mempengaruhi Penurunan Kemamapuan Pasien Skizorenia Dalam Melakukan Perawatan. Jurnal Keperawatan Jiwa, 3(2), 154-161

16. Keliat, B. A., Herawata, N., Panjaitan, R., \& Helena, N. (2011). Proses Keperawatan Kesehatan Jiwa. Jakarta:EGC

17. Nanda. (2012). Diagnosa Keperawatan: Definisi dan Klasifikasi 2012-2014. Jakarta: EGC.

18. Notoatmodjo. S. (2010). Ilmu perilaku kesehatan. Jakarta: Rineka Cipta.

19. Notoatmodjo, S. (2014). Ilmu Perilaku Kesehatan. Jakarta: Rineka Cipta.

20. Nurullah, A. S. (2012). Received and Provided Social Support: a Review of Current Evidence and Future Directions. American Journal of Health Studies: 27(3) 2012, (March 2012), 173-188.

21. Nursalam. (2017). Metodologi Penelitian Ilmu Keperawatan: Pendekatan Praktis. Jakarta: Salemba Medika

22. Padila. (2012). Buku Ajar: Keperawatan Medikal Bedah. Yogyakarta: Nuha Medika.

23. Polit, D.F.,\& Beck, C. T. (2012). Nursing research: Generating and assessing evidence for nursing practice 9th edition. Lippincott William and Wilkins.

24. Primadita, A. (2011). Efektifitas Intervensi Terapi Musik Klasik Terhadap Stress Dalam Menyusun Skripsi Pada Mahasiswa Psik Undip Semarang. PSIK FK UNDIP Semarang, 1-14

25. Riskesdas. (2013). Badan penelitian dan pengembangan kesehatan kementrian kesehatan RI tahun 2013. Laporan Nasional 2013. https://doi.org/1 Desember 2013

26. Riskesdas. (2018). Riset Kesehatan Dasar 2018. Kementrian Kesehatan Republik

27. Saragih, S., \& Indriati, G. (2013). Gambaran tingkat pengetahuan dan sikap keluarga tentang perawatan pasien resiko perilaku kekerasan di rumah. Jurnal Online Mahasiswa Bidang Ilmu Keperawatan, (1).

28.Saryono, A. (2010). Metodologi penelitian kualitatif dalam bidang kesehatan. Yogyakarta: Nuha Medika.

29. Saswati, N., Dasuki, \& Ermayani. (2017). Hubungan Pengetahuan Dan Perilaku Peran Keluarga Dalam Melakukan Perawatan Pasien 
Skizofrenia Di RSJD Provinsi Jambi. Riset Informasi Kesehatan, 6(2), 136.

30. Sugiyono. (2016). Metode Penelitian Pendidikan (Kuantitatif Kualitatif dan $R$ \& D). Bandung: Alfabeta.

31. Susila, I. M. D. P. 2016. Hubungan Tingkat Pengetahuan Dbd Dengan Kejadian DBD Di Banjar Pegok, Desa Sesetan, Kecamatan Denpasar Selatan. Jurnal Dunia Kesehatan. Vol. 5. No. 1. 29 33.

32. Susila, \& Suyanto. (2015). Metodologi Penelitian Cross Sectional. Klaten: Bossscript.

33. Sutini. (2018). Hubungan Dukungan Keluarga Dengan Kualitas Hidup Pasien Gagal Ginjal Kronik Yang Menjalani Hemodialisis Di Rsud Dr. Harjono Kabupaten Ponorogo. Universitas Muhammadiyah Ponorogo.

34. Swasjana I ketut. (2016). Statistik Kesehatan. Yogyakarta: CV Andi Offset
35. Syamsudin, Susilaningsih, I., \& P.S, A. (2015). Dukungan Keluarga Terhadap Gejala Kekambuhan Pasien Gangguan Jiwa Yang Berobat Jalan. Jurnal Keperawatan, 1(1), 7-11.

36. Wahyudin, Ramdani, H. T., \& Rahmi, A. I. B. (2014). Hubungan Antara Tingkat Pengetahuan Keluarga Dengan Kekambuhan Pasien Gangguan Jiwa Di Wilayah Kerja Puskesmas Sukamerangkecamatan Kersamanah Tahun 2014. Implementation Science, 39(1), 1-24.

37. WHO. (2016). SDG Health and Health-Related Targets. World Health Statistics: 2016.

38. Yosep, I. (2010). Keperawatan Jiwa. Bandung: Refia Aditama.

39. Yulianti, I. septia. (2017). Gambaran Dukungan Sosial Keluarga Dan Kualitas Hidup Lansia Dengan Hipertensi Di Puskesmas Citangkil Kota Cilegon. Skripsi 